\title{
Substitution of a fraction of zircon by cristobalite in nano hematite encapsulated pigment and examination of glaze application
}

\author{
Maryam HOSSEINI-ZORI* \\ Department of Inorganic Pigments and Glazes, Institute for Color Science and Technology (ICST), \\ P.O. Box 1668814811, Tehran, Iran
}

Received: January 14, 2013; Revised: February 24, 2013; Accepted: March 14, 2013

CThe Author(s) 2013. This article is published with open access at Springerlink.com

\begin{abstract}
Hematite pigment has a long history, but it cannot be used for ceramic application, because it must be thermally and chemically stable at high firing temperature when using a pigment in a glaze or ceramic body. Recently, through encapsulated systems, a new pigment with suitable thermal and chemical stability can be obtained by encapsulating hematite crystals into selected silica or zircon matrices. It means that nano-sized red hematite has been encapsulated into the protected phases. Transmission electron micrographs of hematite encapsulated into silica and zircon matrices by sol-gel method show spherical single crystals with diameter of about 5-10 $\mathrm{nm}$. In order to optimize ceramic glaze formulations for application of the synthesized red inorganic nanocomposite inclusion pigment by sol-gel method, four different types of glazes (i.e., alkalis, borate, earth alkalis, and leaded glazes) have been tested. The results show that the substitution of a fraction of zircon by cristobalite in hematite-zircon pigment produces acceptable stability with red hue.
\end{abstract}

Keywords: nano hematite; inclusion pigment; zircon; silica; ceramic glaze

\section{Introduction}

In the production of colored ceramic materials, coloring ions can play their roles by being dissolved in the material (ceramic body or glaze) which we intend to color [1-3]. However, these alternatives do not appear to be recommendable in industrial production, since the solution and/or reduction processes involved are rather difficult to control and good reproducibility must always be guaranteed in industrial production. Instead of these procedures, synthetic pigments are widely used in ceramic industry; in these pigments, the color agent has been already incorporated into an

\footnotetext{
* Corresponding author.

E-mail: mhosseini@icrc.ac.ir
}

appropriate host lattice during the calcination stage by some kind of reaction. Of course, the host lattice must have adequate thermal stability and remain insoluble to withstand the aggressive action of the glazes (ceramic frits and/or sintering additives) in which they are formulated. Based on the glaze formulation, some pigments will be useful to apply $[4,5]$.

The inclusion or encapsulation of a reactive, colored or toxic crystal into a highly stable crystalline matrix gives a protection effect to the guest crystal. The guest crystal becomes inactive within the host [6-8]. There is a restricted choice for red/pink and orange colors among synthetic inorganic ceramic pigments to be used in ceramic industry. They are generally easily etched by glasses, and sensitive to the atmosphere and firing temperature; a number of them contain toxic and pollutional elements. Therefore in recent years, there has been a developing interest toward new nontoxic 
inorganic red pigment and applying them into ceramic glazes [4,9-11].

Hematite encapsulated pigment based on silica and/or zircon crystals that protect the occluded red $\alpha-\mathrm{Fe}_{2} \mathrm{O}_{3}$ chromophore crystals is usually utilized, even if the traditional preparation leads to powders that negatively affect the glaze composition and sintering temperature. In particular, in order to achieve high efficiency of chromophore agent encapsulation, the matrix sintering and/or crystallization must be synchronized with the nucleation and growth of the occluded chromophore agent. Crystallization, sintering and inclusion process are thus considered to take place simultaneously, and consequently, the control of particle size of the raw powders is one of the main steps [5-9,12-16].

Silica may be considered to have a potential to be used in the occluded pigment as a matrix due to its properties, relatively low price, and particularly, the sufficient thermal and chemical stability towards glassy phases. The high thermal stability of the silicon lattices and their properties such as the sinter-ability at relatively low temperature are well known [8-11], but an important question is why the hematite-silica pigment is not applied into glaze by ceramic industry? The hematite-silica system presents better red shade pigment than hematite-zircon system, and the hematite-zircon pigment is more expensive than hematite-silica system [17-19].

Based on these considerations, the aim of the present work is to compare the synthesized inclusion pigments in hematite-silica, hematite-zircon, and hematite-silica-zircon systems of several ceramic glazes for applications.

\section{Experimental procedure}

\subsection{Materials}

Samples of $1 \mathrm{~mol} \mathrm{SiO}_{2}-0.2 \mathrm{~mol} \mathrm{Fe}_{2} \mathrm{O}_{3}, 1 \mathrm{~mol} \mathrm{ZrSiO}_{4}-$ $0.2 \mathrm{~mol} \mathrm{Fe}_{2} \mathrm{O}_{3}$, and $\left(0.5 \mathrm{~mol} \mathrm{SiO}_{2}-0.5 \mathrm{~mol} \mathrm{ZrSiO}_{4}\right)_{-}$ $0.2 \mathrm{~mol} \quad \mathrm{Fe}_{2} \mathrm{O}_{3}$ compositions were prepared by colloidal sol-gel method. A concentrated aqueous solution was prepared by adding iron sulfate $\left(\mathrm{FeSO}_{4} \cdot 7 \mathrm{H}_{2} \mathrm{O}\right.$, Merck) in deionized water and refluxing at $70{ }^{\circ} \mathrm{C}$ for $30 \mathrm{~min}$. Then, the required aqueous suspensions of colloidal silica (30 wt $\% \mathrm{SiO}_{2}$, LUDOX) and zirconium chloride (Merck) based on final composition were added to the aqueous solution by drops of the concentrated solution. The systems were continuously stirred and maintained at $70{ }^{\circ} \mathrm{C}$ until the $\mathrm{pH}$ was stabilized at about 4 . The resulting gels were dried at $110{ }^{\circ} \mathrm{C} .0 .2 \mathrm{~mol} \mathrm{NaF}$ as mineralizer or flux agent was applied to all dried gels by milling. The powders were fired at $1000{ }^{\circ} \mathrm{C}$ in an electrical furnace with a soaking time of $3 \mathrm{~h}$. The fired samples were micronized, wet milled and washed in deionized water. Finally three kinds of inclusion pigments were obtained after drying at $110{ }^{\circ} \mathrm{C}$ and screening [20].

Constant $5 \mathrm{wt} \%$ of the pre-synthesized nanocomposite inclusion pigments of the mentioned systems were added to several kinds of transparent ceramic glazes, i.e., earth alkalis (high calcium), borate, alkalis (high sodium), and leaded glazes. All of the colored glazes were formulated by regular amounts of kaolin and additives, then wet milled for $20 \mathrm{~min}$. After air brushing on conventional wall tiles, they were dried at $110{ }^{\circ} \mathrm{C}$ for $2 \mathrm{~h}$ and fired at $1100{ }^{\circ} \mathrm{C}$ in an electrical furnace with a soaking time of $10 \mathrm{~min}$. The heating rate was $20{ }^{\circ} \mathrm{C} / \mathrm{min}$.

\section{2 Characterization methods}

In order to determine the effects of the glaze formulation on the stability of the nanocomposite inclusion pigments and to define the color developed by the samples, a Gretag Macbeth Color-Eye 7000 was used, employing a $10^{\circ}$ standard observer. $L^{*}, a^{*}$ and $b^{*}$ color parameters were measured following CIE (Commission International de l'Eclairage) colorimetric method. In this method, $L^{*}$ is the lightness (black (0) $\rightarrow$ white (100)) axis, $a^{*}$ is the green $(-) \rightarrow \operatorname{red}(+)$ axis, $b^{*}$ is the blue $(-) \rightarrow$ yellow $(+)$ axis, $c^{*}$ is the concentration of color, and $h^{*}$ is the hue factor of color. Particle size analysis of the samples was controlled by a sift mesh (No. 400) and equipment of Mastersizer Malvern with water dispersant.

The microstructures were characterized using a scanning electron microscope (SEM, Leo 1455 VP) equipped with secondary electron (SE) detector and Robinson solid-state backscattered electron (BSE) detector (to display the chemical contrast in the observed objects). The glazes were selected from some ceramic industries; in order to identify their compositions, X-ray fluorescence (XRF) and inductively coupled plasma (ICP) analysis were used.

X-ray diffraction (XRD) patterns have been collected using a conventional powder technique by a Siemens Diffractometer (D500 mod) with $\mathrm{Cu} \mathrm{K \alpha}$ Ni-filtered radiation to identify the crystalline phases 
present in the raw and fired powders.

The powders' microstructure characterization and hematite's morphology have been studied by transmission electron microscopy (TEM, Jeol JEM 2010 with GIF gatan Multiscan Camera 794 and Software Digital Micrograph 3.1).

\section{Results and discussion}

\section{1 Nomenclature of glaze formulations by XRF and ICP analysis}

Table 1 shows the formulations and codes of the four types of frits that have been applied in the colored glazes. They are collected among different glazes. The one with the code of A has higher sodium oxide, so it is called alkalis glaze, and similarly, the borate glaze B, earth alkalis (high calcium) $\mathrm{E}$ and leaded glaze L.

\section{2 Thermal evolution of crystalline phases by XRD analysis}

According to the XRD results in Fig. 1, three phases (i.e., hematite, cristobalite and zircon) crystallize after calcination at $1000{ }^{\circ} \mathrm{C}$ in $\left(0.5 \mathrm{~mol} \mathrm{SiO}_{2}-0.5 \mathrm{~mol}\right.$ $\mathrm{ZrSiO}_{4}$ )-0.2 mol $\mathrm{Fe}_{2} \mathrm{O}_{3}$ sample. Before heat treating, just an amorphous phase with iron chloride crystals can be detected (Fig. 1(a)).

Figures 2 and 3 are related to binary systems of
Table 1 Formulations and codes of the applied frits by XRF and ICP

\begin{tabular}{ccccc}
\hline $\begin{array}{c}\text { Chemical } \\
\text { analysis }\end{array}$ & $\begin{array}{c}\text { Leaded } \\
\text { glaze L }\end{array}$ & $\begin{array}{c}\text { Borate } \\
\text { glaze B }\end{array}$ & $\begin{array}{c}\text { Alkalis } \\
\text { glaze A }\end{array}$ & $\begin{array}{c}\text { Earth alkalis } \\
\text { glaze E }\end{array}$ \\
\hline $\mathrm{SiO}_{2}$ & 57.7 & 55.5 & 51.5 & 57.4 \\
$\mathrm{Al}_{2} \mathrm{O}_{3}$ & 6.82 & 5.47 & 4.30 & 7.53 \\
$\mathrm{Fe}_{2} \mathrm{O}_{3}$ & 0.23 & 0.21 & 0.28 & 0.28 \\
$\mathrm{Na}_{2} \mathrm{O}$ & 4.36 & 5.98 & $\mathbf{1 8 . 4}$ & 5.47 \\
$\mathrm{~K}_{2} \mathrm{O}$ & 1.53 & 1.98 & $\mathbf{4 . 2 9}$ & 1.16 \\
$\mathrm{CaO}$ & 5.17 & 3.21 & 5.65 & $\mathbf{1 1 . 5}$ \\
$\mathrm{MgO}$ & 0.23 & 0.45 & 0.15 & 0.22 \\
$\mathrm{~B}_{2} \mathrm{O}_{3}$ & 0.14 & $\mathbf{2 0 . 8}$ & 4.45 & 6.24 \\
$\mathrm{~Pb}$ & $\mathbf{2 2 . 0}$ & 4.05 & 0.05 & 1.73 \\
$\mathrm{Zn}$ & 1.27 & 2.01 & 7.20 & $\mathbf{8 . 5 1}$ \\
$\mathrm{Zr}$ & 0.40 & 0.21 & 0.04 & - \\
$\mathrm{Cl}$ & 0.06 & 0.10 & 3.72 & - \\
\hline
\end{tabular}

hematite-silica and hematite-zircon respectively. XRD results in Fig. 2 detect hematite and cristobalite phases, and hematite and zircon phases are detected in Fig. 3.

\section{3 Colorimetric analysis of the colored glazes by CIELab values}

CIELab colorimeter results are shown in Tables 2 and 3, providing easy comparison of the stability and color shades of the nanocomposite pigments and a traditional red pigment with code of K4272 made by Reimbold \& Strick Company.

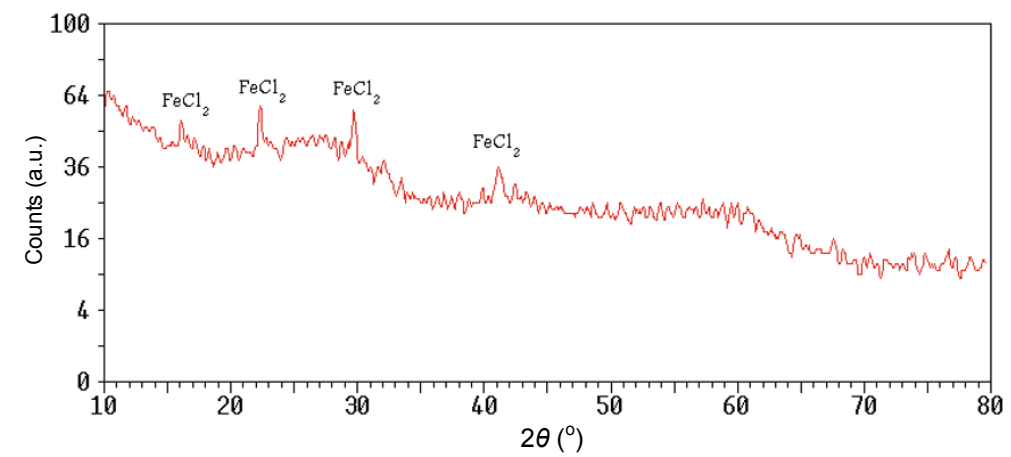

(a)

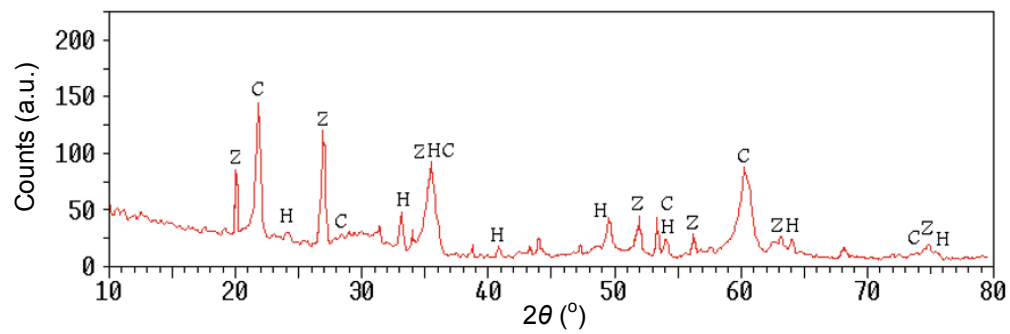

(b)

Fig. 1 XRD patterns of $\left(0.5 \mathrm{~mol} \mathrm{SiO}_{2}-0.5 \mathrm{~mol} \mathrm{ZrSiO}_{4}\right)-0.2 \mathrm{~mol} \mathrm{Fe}_{2} \mathrm{O}_{3}$ sample: (a) raw; (b) after calcination at $1000{ }^{\circ} \mathrm{C}$ for $3 \mathrm{~h} . \mathrm{H}$ : hematite, $\mathrm{C}$ : cristobalite, $\mathrm{Z}$ : zircon. 


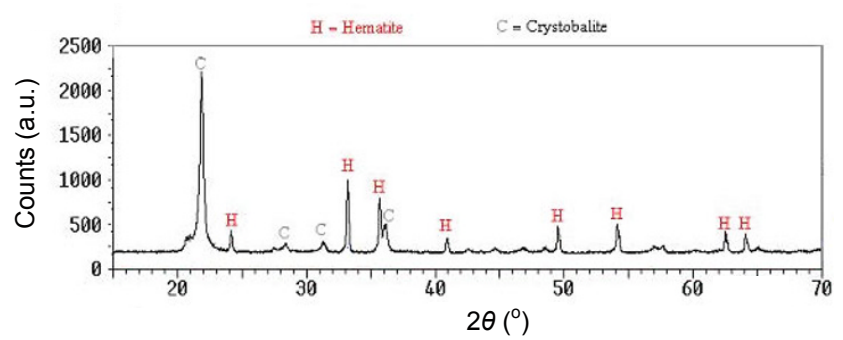

Fig. 2 XRD patterns of the fired sample at $1000{ }^{\circ} \mathrm{C}$ for $3 \mathrm{~h}$ with composition of $1 \mathrm{~mol} \mathrm{SiO}_{2}-0.2 \mathrm{~mol}$ $\mathrm{Fe}_{2} \mathrm{O}_{3}$. H: hematite, C: cristobalite.

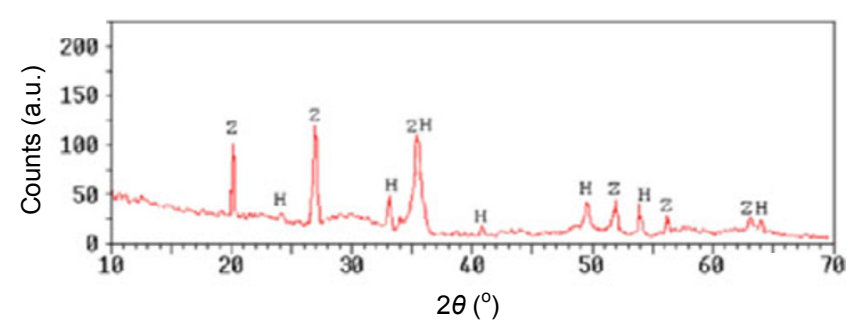

Fig. 3 XRD patterns of the fired sample in $1000{ }^{\circ} \mathrm{C}$ for $3 \mathrm{~h}$ with composition of $1 \mathrm{~mol} \mathrm{ZrSiO}_{4}-0.2 \mathrm{~mol}$ $\mathrm{Fe}_{2} \mathrm{O}_{3}$. H: hematite, $\mathrm{Z}$ : zircon.

Table 2 Color shades and CIELab values of the colored glazes with 5 wt\% of the synthesized nanocomposite inclusion pigments in different systems by light source standard of D65

\begin{tabular}{ccccccc}
\hline Code of frit & Color & $L^{*}$ & $a^{*}$ & $b^{*}$ & $c^{*}$ & $h^{*}$ \\
\hline E & \multicolumn{5}{c}{ Hematite-silica pigment } \\
L & Red & 39.92 & 26.59 & 18.40 & 32.33 & 34.69 \\
A & Light red & 45.21 & 27.49 & 18.80 & 33.30 & 34.36 \\
B & Brown & 39.26 & 13.99 & 11.87 & 18.35 & 40.33 \\
\hline E & Brown & 41.60 & 11.51 & 9.23 & 14.76 & 38.72 \\
\hline L & & Hematite-silica-zircon (ternary) pigment & & 37.63 \\
A & Red & 39.46 & 30.62 & 23.61 & 38.67 & 42.12 \\
B & Red & 47.40 & 30.24 & 27.34 & 40.77 & 35.50 \\
\hline Red & 45.83 & 27.45 & 19.58 & 33.72 & 41.54 \\
\hline E & Red (dark) & 48.50 & 27.55 & 24.41 & 36.80 & \\
A & & & Hematite-zircon pigment & & 20.25 & 29.34 \\
B & Coral & 33.13 & 17.65 & 9.92 & 19.80 & 32.63 \\
\hline
\end{tabular}

Table 3 Color shades and CIELab values of the colored glazes with $5 \mathrm{wt} \%$ of a traditional red pigment in system of $\mathrm{Sn}-\mathrm{Si}-\mathrm{Ca}-\mathrm{Cr}$ by light source standard of $\mathrm{D65}$

\begin{tabular}{ccccccc}
\hline Code of frit & Color & $L^{*}$ & $a^{*}$ & $b^{*}$ & $c^{*}$ & $h^{*}$ \\
\hline E & Coral & 34.47 & 18.00 & 12.20 & 21.74 & 34.13 \\
L & Coral & 35.26 & 14.73 & 9.95 & 17.78 & 34.03 \\
A & Coral & 34.69 & 15.27 & 10.38 & 18.46 & 34.21 \\
B & Coral & 35.40 & 17.97 & 11.88 & 21.55 & 33.47 \\
\hline
\end{tabular}

The color of the glazed tile after firing depends on the system of nanocomposite pigments and glaze formulation. Table 2 presents color shades and CIELab values of the colored glazes with $5 \mathrm{wt} \%$ of the synthesized nanocomposite inclusion pigments in systems of hematite-silica, hematite-silica-zircon (ternary) and hematite-zircon, respectively.

From Table 2 about hematite-silica pigment, it can be seen that the hues of red glazes are different. The best red shade has been obtained by the frit of code $\mathrm{E}$ with high $a^{*} 26.59$ and hue factor 34.69 ; therefore, the glaze based on earth alkalis is more suitable for the application of binary nanocomposite inclusions with colorant agent of hematite and silica matrix. The hematite-silica system of pigment did not have necessary thermal and chemical stability in the glazes except for the earth alkaline frit. Color shades for other glaze formulations are very different from brown to 
light red, thus they are not reliable and consistent enough for industrial application. In point of comparison, a traditional hematite-silica red pigment useful for body stain made by INCO Company was not stable in any glaze. In fact, nano hematite encapsulated in cristobalite phases by the mentioned procedure will introduce better inclusion microstructure and therefore better thermal and chemical stability in comparison with an industrial pigment.

The systems of hematite-silica-zircon (ternary) and hematite-zircon (binary) do not dissolve in these selected glazes, and present approximately unique red-orange shade and red-coral glazes respectively. It seems that the color shade of traditional red pigment with code of $\mathrm{K} 4272$ is more or less similar to the synthesized hematite-zircon pigment.

The cause of changes in the red hues can be studied by SEM.

\section{4 Particle size analysis of the samples}

The synthesized pigment was added in glazes after screening. The particle size of the samples is about $10 \mu \mathrm{m}$. Figure 4 presents a normal curve of particle distribution with $d(0.5): 9.078 \mu \mathrm{m}$ related to one of the samples (hematite-zircon pigment).

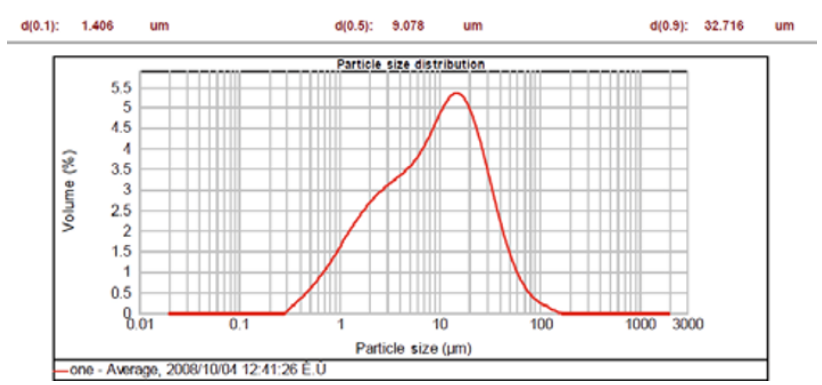

Fig. 4 Particle size analysis of the synthesized hematite-zircon pigment.

\section{5 Microstructure analysis of the samples (pigments and glazes) by SEM and TEM techniques}

TEM micrographs of hematite crystals encapsulated into silica, zircon and both matrices can be seen in Fig. 5. The spherical nanoparticles have diameter of about $5-10 \mathrm{~nm}$.

Figures 5(a) and 5(b) are high magnifications of nano hematite encapsulated into zircon-silica and zircon crystals, respectively. They show that the morphology and size of nano hematite in different systems is more and less similar as in the hematite-silica system seen in Fig. 5(c). The morphology of hematite is important for the color of red pigments [21].

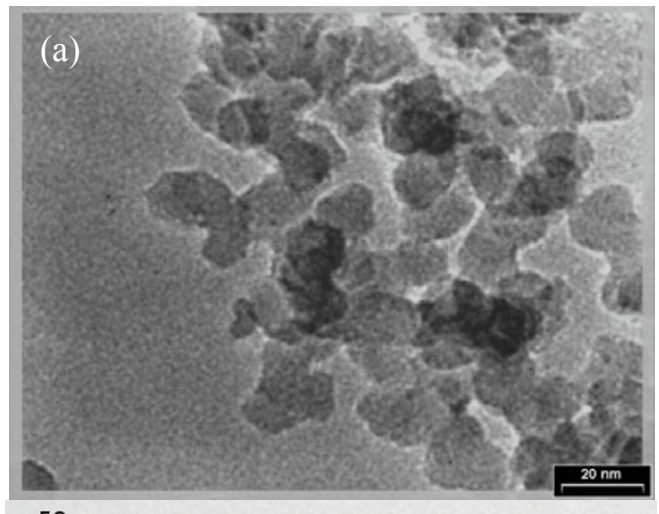

$50 \mathrm{~nm}$

(b)
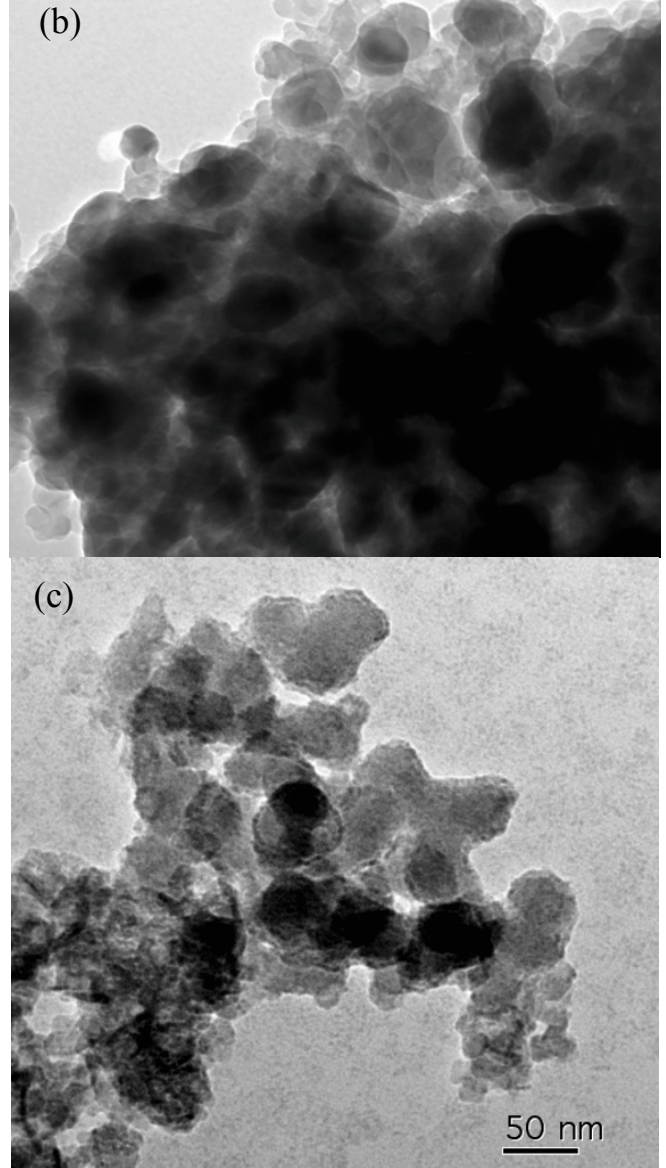

Fig. 5 TEM micrographs of the synthesized

(a) hematite-zircon-silica inclusion pigment,

(b) hematite-zircon inclusion pigment, and

(c) hematite-silica inclusion pigment.

From Fig. 6(a), the microstructure studies of the brown glaze samples related to the colored glaze with $5 \mathrm{wt} \%$ of the synthesized inclusion pigments in system 
of hematite-silica after firing show only some spherical dissolved particles and/or uniformed glassy phase, which indicate that the borate kind of glaze formulation is not useful for the applied system of the nanocomposite pigments, while hematite-zircon pigment in the same glaze show some dispersed particles in the glassy phase (Fig. 6(c)). Borate, leaded and alkalis glazes have the lower viscosity than earth alkalis in the firing of glazes. The viscosity of a molten
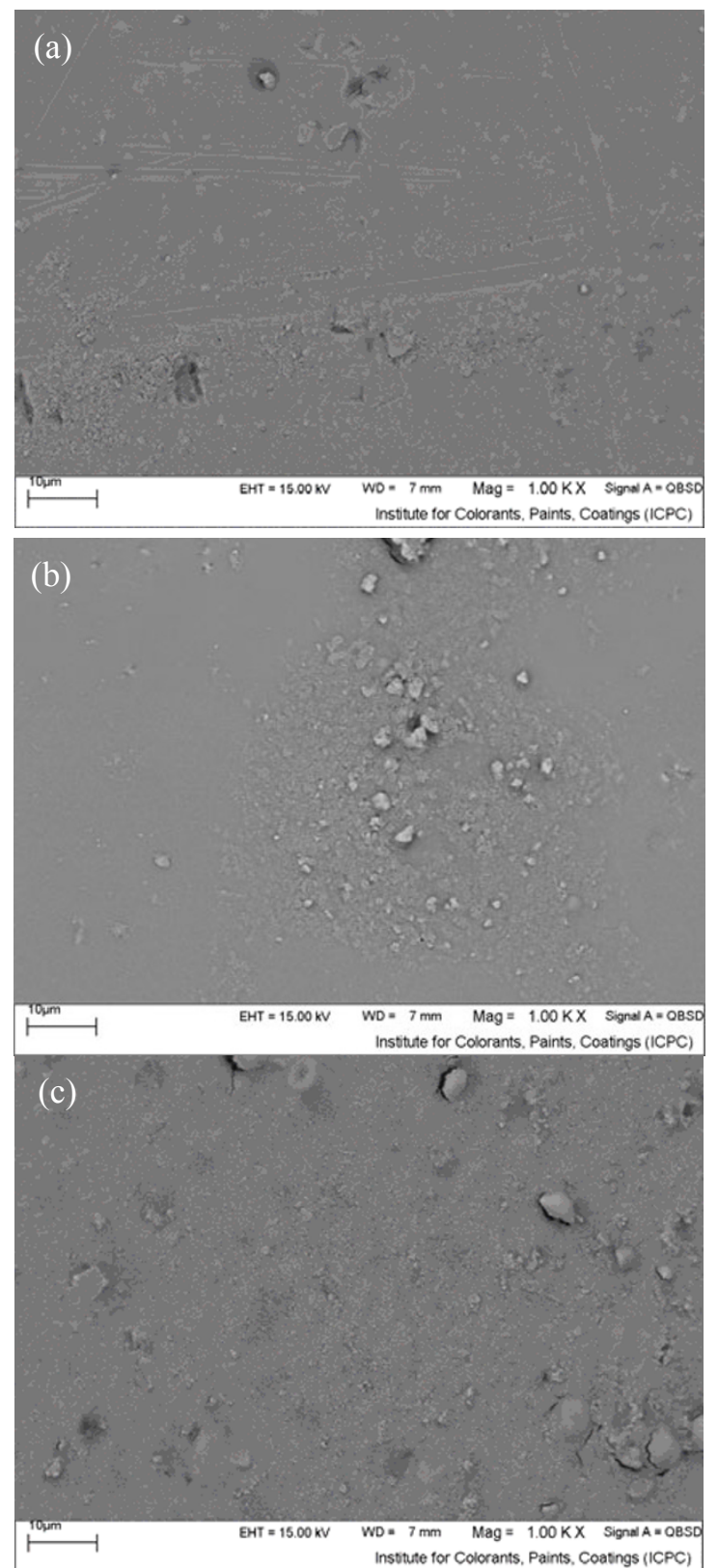

Fig. 6 Microstructures of the brown shade glaze containing $5 \mathrm{wt} \%$ of (a) hematite-silica, (b) hematite-silica-zircon, and (c) hematite-zircon nanocomposite pigments with frit of code B by BSE. glaze affects the mobility of atoms and the speed of diffusion that control the reactions. Gualtieri et al. [22] reported the same result about a natural pigment based on hematite-silica.

The SEM analysis of the red shade glaze samples containing $5 \mathrm{wt} \%$ of hematite-silica nanocomposite inclusion pigment in frit of code $\mathrm{E}$, and/or $5 \mathrm{wt} \%$ of the ternary and binary zircon nanocomposite inclusion pigment in all frits, observe some irregular micron-sized particles dispersed in the glass matrix.

The EDX analysis of the stable particles in the fired glazes prove the presence of $\mathrm{Si}-\mathrm{Fe}$ and/or $\mathrm{Zr}-\mathrm{Si}-\mathrm{Fe}$ elements. It means that these glaze formulations after melting do not attack to nanocomposite pigments. The microstructures of a red shade glaze and point EDX of a stable pigment particle into glaze can be viewed in Fig. 7 (5 wt $\%$ of hematite-silica-zircon nanocomposite pigment with frit of code E) with different magnifications by SE detector.
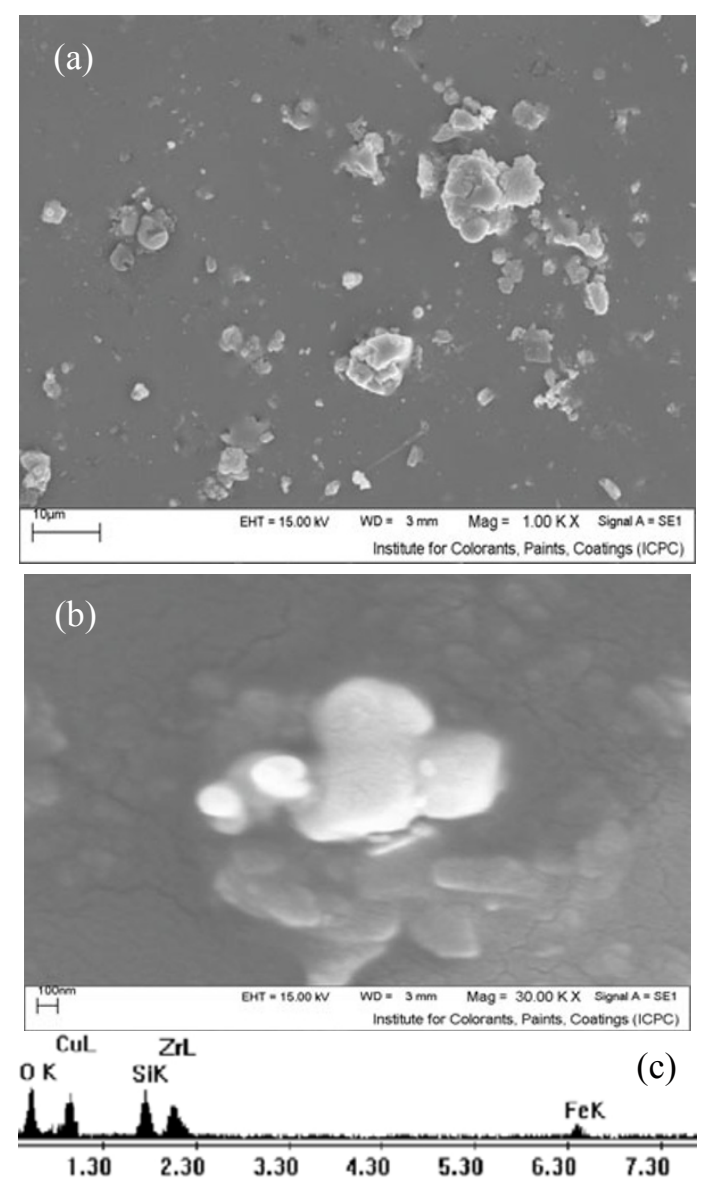

Fig. 7 Microstructures of the red shade glaze $(5 \mathrm{wt} \%$ of hematite-silica-zircon nanocomposite pigment with frit of code E by SE detector ((a) and (b)), and point EDX of a stable particle (c). 


\section{Conclusions}

In order to optimize the ceramic glaze formulations for application of the synthesized red inorganic nanocomposite inclusion pigments by colloidal sol-gel method, several ceramic glazes have been tested. The results show that the best formulation of the glaze with hematite-silica inclusion pigment is $\mathrm{Si}-\mathrm{Ca}-\mathrm{Zn}$ system (earth alkalis glaze). This system is almost applied for the monoprosa tile glazes in ceramic industry. hematite-silica-zircon and hematite-zircon systems of the nanocomposite inclusion pigments have more stability in ceramic glazes than the other system.

Colorimeter data of hematite-zircon system show that this pigment presents more or less similar shades in different types of glazes, and its color can be predicted in every application, so it is more respectable. By the way, hematite-silica-zircon inclusion pigment in earth alkaline glaze presents more intense red shade. Due to the thermal and chemical stability of ternary nanocomposite pigment in some glazes, it may be considered to be a suitable red pigment for ceramic applications.

A fraction of zircon is substituted by silica in the mentioned pigment; therefore, it can be obtained cheaper than hematite-zircon pigment. On the other hand, it shifts coral shade of hematite-zircon pigment to better or different red hue and performs new red pigment.

\section{Acknowledgements}

We are grateful to Mashad Glaze Industrial Group for the provision of the glazes used.

Open Access: This article is distributed under the terms of the Creative Commons Attribution Noncommercial License which permits any noncommercial use, distribution, and reproduction in any medium, provided the original author(s) and source are credited.

\section{References}

[1] Bondioli F, Ferrari AM, Leonelli C, et al. Synthesis of $\mathrm{Fe}_{2} \mathrm{O}_{3} /$ silica red inorganic inclusion pigments for ceramic application. Mater Res Bull 1998, 33: 723-729.

[2] Candeia RA, Bernardi MIB, Longo E, et al. Synthesis and characterization of spinel pigment $\mathrm{CaFe}_{2} \mathrm{O}_{4}$ obtained by the polymeric precursor method. Mater Lett 2004, 58: 569-572.

[3] Sorli S, Tena MA, Badenes JA, et al. Structure and color of $\mathrm{Ni}_{x} \mathrm{~A}_{1-3 x} \mathrm{~B}_{2 x} \mathrm{O}_{2}(\mathrm{~A}=\mathrm{Ti}, \mathrm{Sn} ; \mathrm{B}=\mathrm{Sb}, \mathrm{Nb})$ solid solutions. J Eur Ceram Soc 2004, 24: 2425-2432.

[4] Harisanov V, Pavlov RS, Marinova IT, et al. Influence of crystallinity on chromatic parameters of enamels coloured with malayaite pink pigments. $J$ Eur Ceram Soc 2003, 23: 429-435.

[5] Hosseini-Zori M, Taheri-Nassaj E, Mirhabibi AR. Effective factors on synthesis of the hematite-silica red inclusion pigment. Ceram Int 2008, 34: 491-496.

[6] Bondioli F, Manfredini T, Siligardi C, et al. A new glass-ceramic red pigment. J Eur Ceram Soc 2004, 24: 3593-3601.

[7] Hosseini-Zori M. Synthesis of inclusion nano composite as a non toxic red ceramic pigment by sol-gel method. In Ceramic Transactions Volume 210: Ceramic Materials Components for Energy and Environmental Applications. Jiang DL, Zeng YP, Singh M, et al. Eds. Hoboken: John Wiley \& Sons, 2010: 60-65.

[8] Hosseini-Zori M, Bondioli F, Manfredini T, et al. Effect of synthesis parameters on hematite-silica red pigment obtained using a coprecipitation route. Dyes Pigments 2008, 77: 53-58.

[9] Bondioli F, Manfredini T. The search for new red pigments. Am Ceram Soc Bull 2000, 79: 68-70.

[10] Vicent JB, Llusar M, Badenes J, et al. Occlusion of chromophore oxides by sol-gel methods: Application to the synthesis of hematite-silica red pigments. Bol Soc Esp Cerám Vidrio 2000, 39: 83-93.

[11] Hosseini-Zori M, Taheri-Nassaj $\quad$ E. Nano encapsulation of hematite into silica matrix as a red inclusion ceramic pigment. J Alloys Compd 2012, 510: $83-86$.

[12] Hradil D, Grygar T, Hradilová J, et al. Clay and iron oxide pigments in the history of painting. Appl Clay Sci 2003, 22: 223-236.

[13] Dondi M, Matteucci F, Cruciani G. Zirconium titanate ceramic pigments: Crystal structure, optical spectroscopy and technological properties. J Solid State Chem 2006, 179: 233-246.

[14] Llusar M, Badenes JA, Calbo J, et al. Environmental and colour optimisation of mineraliser addition in synthesis of iron zircon ceramic pigment. Br Ceram Trans 2000, 99: 14-22.

[15] Bondioli F, Manfredini T, Siligardi C, et al. New glass-ceramic inclusion pigment. J Am Ceram Soc 2005, 88: 1070-1071. 
[16] Ricceri R, Ardizzone S, Baldi G, et al. Ceramic pigments obtained by sol-gel techniques and by mechanochemical insertion of color centers in $\mathrm{Al}_{2} \mathrm{O}_{3}$ host matrix. J Eur Ceram Soc 2002, 22: 629-637.

[17] Garcia A, Llusar M, Badenes J, et al. Encapsulation of hematite in zircon by microemulsion and sol-gel methods. J Sol-Gel Sci Technol 2003, 27: 267-275.

[18] Nero GD, Cappelletti G, Ardizzone S, et al. Yellow Pr-zircon pigments the role of praseodymium and of the mineralizer. $J$ Eur Ceram Soc 2004, 24: 3603-3611.

[19] García A, Llusar M, Sorlí S, et al. Effect of the surfactant and precipitant on the synthesis of pink coral by a microemulsion method. J Eur Ceram Soc 2003, 23: 1829-1838.

[20] Hosseini-Zori M. Synthesis of the new ternary nano composite pigment of hematite-zircon-silica by sol-gel method. Iran Patent PV 49877, 2008.

[21] Katsuki H, Komarneni S. Role of $\alpha-\mathrm{Fe}_{2} \mathrm{O}_{3}$ morphology on the color of red pigment for porcelain. J Am Ceram Soc 2003, 86: 183-185.

[22] Gualtieri AF. Natural red pigment for single-fired ceramic glaze. Ceram Bull 2002, 81: 48-52. 